\title{
PERAN PRAMUWISATA DI KAWASAN KONSERVASI GEOPARK, BATUR KINTAMANI
}

\author{
NMS Wijaya ${ }^{1}$, Ni Putu Eka Mahadewi ${ }^{2}$, Kresnanda Yuliono ${ }^{3}$, Ni Wayan Jeni Purwani ${ }^{4}$ \\ Program Studi Industri Perjalanan Wisata, Fakultas Pariwisata, Universitas Udayana \\ ${ }^{1}$ Email: sofia_ipw@unud.ac.id \\ Program Studi Industri Perjalanan Wisata, Fakultas Pariwisata, Universitas Udayana \\ 2Email: eka.mahadewi23@gmail.com \\ Program Studi Industri Perjalanan Wisata, Fakultas Pariwisata, Universitas Udayana \\ ${ }^{3}$ Email: kresnanda.yuliono@gmail.com \\ Program Studi Industri Perjalanan Wisata, Fakultas Pariwisata, Universitas Udayana \\ ${ }^{4}$ Email: purwanipurwanijeni@gmail.com
}

\begin{abstract}
Geopark as a conservation area has a potential for biodiversity, geological diversity, and culture. This diversity of potential is developed as an integral part of the Geotourism area. This research was conducted in the Gunung Batur conservation area and the purpose of this study was to determine the role of guides through the delivery of information provided to tourists to contribute to the protection of the Batur geopark conservation area as sustainable tourism. The role of the guide was identified through the perception of tourists by distributing questionnaires to 100 respondents. The results of the study state that there are two variables, namely the communicator mediator and the Research management role of environmental interpreter in the category "Simply Agree". The subindicators of the variable are "Explain potential (geology) as the main potential of the conservation area" with a score of 52.8 percent; "Explain the activities of local communities in the conservation area" with a score of 59.4 percent; "Describe natural resources, vegetation and habitat at the climbing location" with a score of 50 percent. The three sub-indicators are indicators that are the main function of the role of guides in the conservation area, but this sub-indicator gets the lowest percentage, therefore it is interpreted that the role of guides in the Batur Kintamani Geopark conservation area still needs improvement in interpreting information related to socio-cultural potential, as well as geology as a potential for conservation, and natural resources.
\end{abstract}

\begin{abstract}
Abstrak: Geopark sebagai kawasan konservasi mempunyai potensi keaneka ragaman hayati, keaneka ragaman geologi, dan budaya. Keaneka ragaman potensi ini dikembangkan sebagai bagian yang integral sebagai kawasan Geotourism.Penelitian ini dilakukan di wilayah konservasi gunung Batur dan tujuan penelitian ini adalah untuk mengetahui peran pramuwisata melalui penyampaian informasi yang diberikan kepada wisatawan untuk berkontribusi pada perlindungan kawasan konservasi geopark Batur sebagai pariwisata berkelanjutan.Peran pramuwisata diidentifikasi melalui persepsi wisatawan dengan menyebarkan kuisioner kepada 100 responden.Hasil penelitian menyatakan bahwa terdapat dua variabel yaitu communicator mediator dan Research management role of environmental interpreter dengan kategori "Cukup Setuju". Adapun sub indikator pada variable tersebut adalah "Menjelaskan potensi (geologi) sebagai potensi utama wilayah konservasi" dengan skor 52,8 persen; "Menjelaskan aktivitas masyarakat lokal di wilayah konservasi" dengan skor 59,4 persen; "Menjelaskan sumber daya alam, vegetasi dan habitat di lokasi pendakian" dengan skor 50 persen. Ketiga sub indikator tersebut merupakan indikator yang menjadi fungsi utama dari peran pramuwisata di wilayah konservasi, namun sub indikator ini mendapatkan persentase paling rendah sehingga diinterpretasikan bahwa peran pramuwisata di kawasan konservasi Geopark Batur Kintamani masih memerlukan peningkatan dalam memberikan interpretasi informasi yang terkait dengan potensi sosial-budaya, geologi sebagai potensi konservasi, dan sumber daya alam.
\end{abstract}

Keywords: guide, conservation, kintamani geopark, geotourism. 


\section{PENDAHULUAN}

Kawasan Kintamani merupakan salah satu Kawasan Daya Tarik Wisata Khusus (KDTWK) yang telah ditetapkan dengan Peraturan Daerah Provinsi Bali Nomor 16 tahun 2009 tentang rencana Tata Ruang Wilayah( RTRW) Provinsi Bali. Penetapan Kawasan Kintamani sebagai Global Geopark (Taman Bumi Dunia) menjadi potensi utama dalam mendukung pengembangan Kintamani sebagai Kawasan Daya Tarik Wisata Khusus (KDTWK). Kawasan Kintamani - Danau Batur dan sekitarnya memiliki banyak potensi baik panorama alam, budaya maupun hasil alam yang dapat dijadikan sebagai sumber mata pencaharian warga. Salah satu potensi alam yang dimiliki adalah kaldera. Kaldera Gunung Batur diperkirakan terbentuk akibat dua letusan besar 29.300 tahun dan 20.150 tahun yang lalu. Kawasan Kaldera Batur yang meliputi seluruh 15 desa yang terletak di dalam Kaldera Batur dan 33 desa yang berada di luar Kaldera Batur telah ditetapkan oleh Badan Dunia UNESCO sebagai bagian dari Global Geopark Network (GGN) saat Konferensi Geopark Eropa yang ke-11 pada tanggal 20 September 2012 di Auroca Geopark, Portugal.

Saat ini, GGN berada di bawah komisi keilmuan (Science) UNESCO Global Geopark (UGG) mempergunakan pendekatan yang sifatnya inovatif terhadap kawasan yang memiliki karakteristik geologi serta dipromosikan oleh Unesco menjadi suatu kawasan dilindungi karena wilayah tersebut mengandung sejumlah situs warisan geologi yang memiliki ciri yang spesifik, jarang ditemukan di wilayah lain atau memiliki sisi keindahan formasi geologi.Tujuan utama dari Geopark mencakup tiga hal yang saling terkait yaitu: (1) Konservasi/perlindungan aspek geologis; (2) Edukasi, terhadap fenomena pembetukan muka bumi (geoscientific knowledge); (3) Geotourism, kegiatan geopark mampu menjadi stimulus aktivitasekonomi bagi masyarakat dan pembangunan yang berkelanjutan (Master Plan Batur Geopark). Konsep geopark dan pengembangannya akan diimplemantasikan di kawasan Kaldera Gunung Batur, Kecamatan Kintamani, Kabupaten Bangli, Provinsi Bali, yang secara geomorfologi merupakan kawasan gunung api. Geopark Batur sebagai kawasan konservasi dimana prinsip keberlanjutan merupakan pondasi dasar yang harus diterapkan dalam pengembangan kawasan konservasi. beberapa hasil penelitian yang berhubungan dengan peran pramuwisata, geopark, geotourism konservasi. Penelitian yang dilakukan oleh Cohen (1985) menjelaskan peran pramuwisata sebagai pemandu dalam hal pengelolan kelompok atau kemampuan pramuwisata dalam mengatur dan menghibur kelompok dan juga sebagai mediasi.

Penelitian kedua menurut Randall (2008) mengeksplorasi poran pramuwisata yang memiliki potensi untuk berkontribusi pada pelestarian dan perlindungan potensi alam. Ada teknik penelitian yang digunakan untuk mengukur peran pramuwisata adalah dengan menggunakan persepsi pramuwisata yang dilakukan dengan dua pendekatan yaitu pre dan post perseption.

Penelitian selanjutnya yaitu penelitian dari Weiler dan Walker (2004) menjelaskan telah terjadi alih peran pramuwisata dalam kaitannya dengan keberlanjutan suatu kawasan, termasuk memperbaiki tingkat pemahaman terhadap value dari situs peninggalan, masyarakat, dan lingkungan. Selain itu mengawasi perilaku wisatawan dan mempengaruhi atau mendorong berperilaku pro-konservasi.

Pemandu wisata memiliki peran khusus terutama pada jenis wisata seperti ekowisata atau pariwisata alternatif. Jenis pariwisata ini memerlukan keahlian dalam interpretasi, memotivasi pengunjung untuk mengubah perilaku mereka untuk meminimalkan dampak terhadap sumber daya dan menanamkan nilai konservasi. (Black, 2007). Pramuwisata geotourism harus memiliki peran kunci dan terutamaperan spesifik seperti interpretatif, informatif, edukatif dan protektif. Definisi pramuwisata geotour muncul dengan mengadopsi definisi geotourism yang dikemukakan oleh Hose (2000). Artinya, "Pramuwisatageotour adalah orang yang menafsirkan situs geologi dan geomorfologi dan material mereka, mempromosikan geokonservasi untuk memastikan pariwisata berkelanjutan dan, meningkatkan pengetahuan dan kesadaran wisatawan terhadap warisan geologi dan keanekaragaman hayati serta memastikan pengalaman wisatawan yang berkualitas".

$$
\text { Cohen (1985) pertama kali }
$$
mengkonseptualisasikan peran pramuwisata ini dalam empat peran yang berbeda. Orientasi peran "outer directed" dari 
pramuwisata adalah terhadap organisasi dan manajemen ( instrumental roles) dan fasilitasi pertemuan dengan populasi tuan rumah (social roles). Peran pemandu wisata "inner-directed" menekankan pada kepemimpinan dalam bentuk interaksi sosial (social role) dan penyebaran informasi (communikation role). Empat peran pemandu wisata Cohen dapat diringkas sebagai berikut:

(1) The Instrumental Role: focusing on direction-giving, navigation, access to the territory and safety;

(2) The Interactional Role:focusing on representation of the area to the followers in a non-threatening manner and organisation ;

(3) The Social Role:focusing on tension management, social integration and cohesion and using humor and entertainment to maintain and build group morale;

(4) The Communicative Role: focusing on selecting points of interest for the group, dissemination of correct information and the translation of the unfamiliar (Cohen, 1985).

Weiler dan Davis (1993), menjelaskan peran pemandu dalam pariwisata berbasis alam menekankan bahwa model Cohen tidak memasukkan kebutuhan lingkungan alam, oleh karena itu pemandu wisata harus memiliki fokus ketiga, lingkungan alam, atau istilahnya yang disebut" manajemen sumber daya". Fokus manajemen sumber daya ini berisi dua peran (Gambar 1): "motivator" (modifikasi perilaku dan dampak wisata di tempat) dan "juru bahasa lingkungan" (pemahaman dan penghargaan terhadap isu lingkungan untuk memfasilitasi perilaku wisatawan yang bertanggung jawab dalam jangka panjang) (Weiler \& Davis, 1993, hal 232)
Gambar 1. Geotour Guide's Roles

\begin{tabular}{|c|c|c|}
\hline & Outer Directed & Inner Directed \\
\hline $\begin{array}{l}\text { Leadership } \\
\text { (focus on group) }\end{array}$ & $\begin{array}{l}\text { Instrumental } \\
\cdot \text { direction } \\
\text { - access } \\
\cdot \text { control }\end{array}$ & $\begin{array}{l}\text { Social } \\
\text { - tension } \\
\text { management } \\
\text { • integration } \\
\cdot \text { morale } \\
\text { - animation }\end{array}$ \\
\hline $\begin{array}{l}\text { Mediatory } \\
\text { (focus on } \\
\text { individual) }\end{array}$ & $\begin{array}{l}\text { Interactionary } \\
\text { •representation } \\
\text { • organisation }\end{array}$ & $\begin{array}{l}\text { Communicative } \\
\text { - selection } \\
\text { - information } \\
\text { - interpretation } \\
\text { - fabrication }\end{array}$ \\
\hline $\begin{array}{l}\text { Resource Manager* } \\
\text { (focus on } \\
\text { geosite/geopark) }\end{array}$ & $\begin{array}{l}\text { Motivator } \\
\text { - modification of } \\
\text { tourist } \\
\text { behavior and } \\
\text { impacts on } \\
\text { geosite/geopark }\end{array}$ & $\begin{array}{l}\text { Geosite Interpreter } \\
\text { - promote long- } \\
\text { term } \\
\text { environmental } \\
\text { behaviors }\end{array}$ \\
\hline
\end{tabular}

Sumber: Cohen's (1985) and Weiler dan Davis's (1993)

Semua aktivitas pariwisata mempunyai tujuan harus berkontribusi terhadap realisasi pengembangan yang berkelanjutan (Tosun, 1998). Untuk itu Geopark batur sebagai kawasan konservasi membutuhkan pramuwisata yang memiliki peran untuk mempengaruhi dan memperbaiki perilaku pengunjung dengan memastikan bahwa mereka harus bertanggung jawab terhadap lingkungan dan berkontribusi pada keberlanjutan kawasan serta memiliki pengaruh pada wisatwan untuk memiliki sikap ramah kepada lingkungan (Armstrong \& 1999). Sehingga, peran pramuwisata menjadi sangat penting (Cohen, 1985). Namun terdapat kenyataan bahwa masyarakat dan wisatawan masih banyak yang belum paham terhadap fungsi dan manfaat geopark itu sendiri. Sehingga disinilah peran dan tanggung jawab pramuwisata untuk dapat memberikan informasi yang benar kepada wisatawan dan masyarakat. Berdasarkan latar belakang tersebut diatas maka penting dalam penelitian ini dikaji tentang investigasi peran 
pramuwisata melalui persepsi wisatawan praktek dalam kepemanduan di kawasan konservasi Geopark, Batur. Selain itu, penelitian ini berkontribusi pada literatur pembangunan berkelanjutan dan meningkatkan pengetahuan wisatawan dan masyarakat terhadap warisan geologi dan keaneka ragaman hayati serta peningkatan pengelolaan pemandu wisata (pramuwisata).

\section{METODE}

Penelitian ini dilakukan di Kawasan Konservasi Pendakian Gunung Batur Geopark, Desa Songan, Kecamatan Kintamani, Bangli. Pengukuran Peran Pramuwisata yang menjadi fokus penelitian adalah menggunakan enam peran pramuwisata menurut Cohen (1985). Untuk mengetahui peran pramuwisata di kawasan konservasi geopark dapat dilihat pada variabel peran berikut ini:

Tabel 1. Variabel Peran

\begin{tabular}{ll}
\hline $\begin{array}{l}\text { Variabel } \\
\text { Peran }\end{array}$ & \multicolumn{1}{c}{ Indikator } \\
\hline $\begin{array}{l}\text { Outer- } \\
\text { directed }\end{array}$ & $\begin{array}{l}\text { Instrumental } \\
\text { leadership }\end{array}$ \\
\cline { 2 - 2 } & $\begin{array}{l}\text { Interactionary } \\
\text { mediator }\end{array}$ \\
\hline $\begin{array}{l}\text { Inner- } \\
\text { directed }\end{array}$ & Social Leadership \\
\cline { 2 - 2 } & $\begin{array}{l}\text { communicator } \\
\text { mediator }\end{array}$ \\
\cline { 2 - 2 } & $\begin{array}{l}\text { Research } \\
\text { management role } \\
\text { of motivator }\end{array}$ \\
\cline { 2 - 2 } & $\begin{array}{l}\text { Research } \\
\text { management role } \\
\text { of environmental } \\
\text { interpreter }\end{array}$ \\
\hline
\end{tabular}

Teknik pengumpulan data yang digunakan adalah observasi, kuesioner, dokumentasi dan studi kepustakaan. Teknik penentuan sampel ditentukan secara purposive menggunakan rumus Slovin.

Berdasarkan hasil penghitungan di atas maka jumlah sampel pada penelitian ini adalah 100 orang wisatawan. Sedangkan pengambilan sampel dilakukan secara accidental, yang dimaksud dengan accidental adalah responden dalam penelitian ini adalah wisatawan yang kebetulan ditemui saat menyebaran kuisioner di kawasan konservasi pendakian gungn batur sebagai wilayah Geopark Batur Kintamani.
Penelitian dilakukan menggunakan teknik analisis data penelitian kuantitatif kualitatif, dengan teknik pengumpulan data dengan menggunakan kuisioner.Penelitian deskriptif dimaksudkan untuk mengeksplorasi dan mengklarifikasi suatu fenomena atau kenyataan sosial dengan jalan mendeskripsikan sejumlah variabel yang berkenaan dengan masalah dan unit yang diteliti (Faisal, 2001: 20). Responden yang dipilih dengan aksidental yang berkunjung ke wilayah konservasi pendakian gunung Batur bersama dengan pramuwisata lokal.

Penelitian ini dimaksudkan untuk mengeksplorasi dan mengklarifikasi peran pramuwisata lokal di wilayah konservasi Geopark, kawasan pendakian gunung Batur Kintamani. Untuk penyajian data dilakukan dalam bentuk uraian singkat, bagan, dan tabel. Pengolahan data secara kuantitatif dilakukan khususnya mengenai peran pramuwisata melalui persepsi wisatawanyang akan mempergunakan bantuan skala likert. Untuk penggunaan skala likert, pada setiap pernyataan yang diajukan terdapat 5 pilihan alternative jawaban yang memiliki bobot 1 hingga 5.Untuk penilaian interpretasi wisatawan terhadap peran pramuwisata adalah hasil nilai yang dihasilkan dengan menggunakan rumus Index \%.

\section{HASIL DAN PEMBAHASAN}

Kecamatan Kintamani merupakan salah satu dari empat kecamatan yagn terdapat di Kabupaten Bangli dengan luas wilayah sebesar 36.692 Ha.Secara geografis Kecamatan Kintamani tereltak di bagian Timur Laut Provinsi Bali dan bagian utara dari kabupaten Bangli dan terletak di kawasan perbukitan dan pegunugnan Bali. Secara administrasi Kecamatan Kintamani terbagi dalam 48 desa, 171 banjar dinas/dusun dengan jumlah penduduk 91.796 jiwa pada tahun 2010.Adapun lokasi penelitian ini terletak di Kawasan Taman Wisata Alam (TWA) Gunung Batur Bukit Payang.TWA Gunug Batur Bulit Payang berada di wilayah Seksi Konservasi Wilayah II Balai KSDA Bali.

Dengan ditetapkannya Gunung Batur sebagai Geopark oleh UNESCO sejak Oktober 
2010, kawasan ini mengalami peningkatan kunjungan wisatawan domestic dan wisatawan mancanegara. Beberapa potensi wisata yang terdapat di kawasan Geopark Gunung Batur diantaranya adalah Trekking, pendakian Gunung Batur, Cycling, Wisata religi dan budaya, camping, fotografi, wisata kesehatan, wisata geopark, dan pemandian air panas.

Adapun potensi sosial budaya masyarakat sekitar kawasan TWA Gunung Batur Bukit Payang masih menjalankan kebiasaan dan tradisi seperti gotong-royong, dan struktur adat yang khas. Kesenian tradisional yang masih ada di di masyarakat seperti kelompok seni tari tarian sacral seperti tari Baris Gede, baris Tojor, Baris Tombak, Tari Rejang dan Wayang. Kesenian gamelan adalah Gender Wayang, Gong Gede, Gong Kebyar, Kidung, Kekawin, Geguritan yang digunakan jika ada upacara adat keagamaan.

Kawasan konservasi di Batur Kintamani merupakan satu-satunya kawasan konservasi yang ditetapkan sebagai Global Geopark di Bali. Ada beberapa hal Batur diusulkan menjadi Geopark yaitu:

1. Menurut van Bemmelen (1949), Kaldera Batur merupakan salah satu kaldera terindah di dunia, berukuran sekitar $13,8 \times 10 \mathrm{~km}$, dan struktur kaldera lainnya terbentuk di tengahnya dengan diameter 7,5 $\mathrm{km}$

2. Erupsi Batur Purba menghasilkan endapan abu sangat tebal, emmadat, disebut paras saat ini digali dijadikan batako untuk bahan bangunan pura, patung dan lainnya.

3. Mempunyai keunikan biodervisity yang dikelola oleh Taman Wisata Alam, umumnya tanaman hutan yang terdiri atas beberapa spesies.

Strategi Pengembangan Geopark berpilar pada:

1. Aspek perlindungan dan konservasi

2. Aspek pendidikan yaitu menyelenggarakan dan menyediakan informasi kepada public tentang pengetahuan geosains serta konsep lingkungan dan budaya.

3. Aspek pengembangan nilai ekonomi lokal melalui kegiatan pariwisata (geotourism) berkelanjutan yang bersumber dari 3 pilar pengembangan Geopark yaitu Keragaman Geologi (Geological diversity), Keragaman hayati (Biodiversity), keragaman Budaya (cultural diversity).
Berdasarkan Master Plan Batur Blobal Geopark (Pemerintah kabupaten Bangli, 2014), dijelaskan Potensi dan Kawasan Batur Global Geopark adalah sebagai berikut:

- Bentang alam berbukit dan adanya Bunung Batur dengan panorama yang menarik dan indah berpotensi sebagai pariwisata alam.

- Adanya danau Batur berpotensi sebagai sumber mata air dan pengembangan wisata air.

- Memiliki daya tarik pemandangan alam, danau, lembah, perkebunan sebagai daya tarik investasi pengembangan pariwisata.

Wilayah konservasi Batur, Kintamani merupakan wilayah yang dilindungi dibawah pengelolaan Balai Konservasi dan Sumber Daya alam (BKSDA), Bali.Di kawasan kaldera Batur ini sudah berjalan beberapa upaya konservasi terwujud dalam bentuk Taman Wisata Alam (TWA). Beberapa kegiatan jasa yang ada di wilayah konservasi diantaranya pendakian, traking, dan cycling dikelola oleh masyarakat lokal di Desa Batur, dengan berbasis pada Ijin Usaha Penyediaan Jasa Wisata Alam(IUPJWA) dari BKSDA. Terutama untuk kegiatan pendakian memiliki pengelolaan khusus oleh Forum Pramuwisata Pendakian Gunung Batur (FP2GB).Forum ini mengelola pemandu wisata lokal yang berjumlah 382 orang. Namun pemandu wisata lokal yang aktif berjumlah 250 orang.FP2GB memiliki wewenang dalam mengatur rotasi bagi pemandu wisata pendakian yang bertugas di gunung Batur.Setiap harinya yang bertugas rata-rata adalah 100 pemandu, dimana 1 orang pemandu boleh memandu wisatawan maksimal 5 orang. Peran pramuwisata memiliki beberapa penjelasan yang berbedabeda , diantaranya menurut Maurice \& Cohen (2002) dan Yu, Weiler dan Ham (2001), peran pramuwisata adalah

- A leader capable of assuming responsibility.

- An information giver and fountain of knowledge.

- A mentor (the role of the mentor resembles the role of teacher, tutor, instructor or advisor).

- A mediator and cultural brokerage; several studies have suggested that tour guides play a direct role in mediating cultural exchange between visitors and host 
cultures. An educator to help tourists understand the places they visit.

- An educator to help tourists understand lots of topics such as politics, economy, society, culture, religion, general knowledge, education, health, etc.

- An ambassador extending hospitality and presents the destination in a way that makes visitors want to return.

- A host creating a comfortable environment for tourists and a person influencing the quality of service and the tourist experience, the length of stay and the resulting economic benefits for a local community.

Menurut Leclerc dan Martin (2004), pramuwisata berperan dalam menyediakan informasi dan dapat bercerita tentang tempat yang dikunjungi. Sedangkan menurut Cohen, terdapat 6 peran pramuwisata yang digunakan sebagai variabel dari penelitian ini yaitu outer directed yang terdiri dari :instrumental, interactionaly, motivator dan Inner directed yang terdiri dari: sosial, komunikatif , environmental interpreter.

Berdasarkan data yang diperoleh dari salah satu anggota FP2GB, yaitu I Ketut Setiawan terdapat 55 orang pramuwisata yang sudah memiliki lisensi kepemanduan yang ijinnya dikeluarkan oleh BKSDA.Selain lisensi yang dikeluarkan oleh BKSDA, pramuwisata tersebut juga memiliki lisensi dari Himpunan Pramuwisata Indonesia (HPI) dalam menunjang tugas mereka sebagai pemandu dengan standar profesionalisme. Untuk menjalankan tugas sebagaipemandu wisata HPI menerapkan batasan yang diatur dalam kode etik pramuwisata yang bersumber dari ketetapan rapat kerja nasional VIII HPI, 28-30 November 2007 di Manado dengan pengayaan ketentuan UU No. 10/ Tahun 2009 dan PP No. 52 /Tahun 2012. Guna menjalankan tugas dan disiplin profesi yang penuh tanggung jawab, seperti yang dijelaskan dalam dokumen kode etik HPI alinea tiga tentang kewajiban diri pramuwisata sebagai berikut:

1. Pramuwisata dalam melaksanakan tugas harus selalu patuh terhadap hukum dan perundang-undangan yang berlaku di Republik Indonesia.

2. 2. Menjaga citra baik kepariwisataan Indonesia yang berdasarkan kepada falsafah Pancasila sebagai pandangan hidup bangsa Indonesia.
3. Taat memakai kartu lisensi yang dikeluarkan oleh pemerintah atau pihak berwenang dalam menjalankan tugas.

4. Wajib peduli dengan lingkungan hidup berdasar atas masterplan yang telah menjadi keputusan daerah dan pusat.

5. Memahami tentang kebudayaan masyarakat setempat, adat istiadat yang berlaku dalam pengembangan kepariwisataan daerah yang bersangkutan.

6. Menjaga reputasi sesama pramuwisata dan partner kerja baik sengaja maupun tidak sengaja.

7. Dilarang keras memberikan informasi kepada wisatawan terhadap rahasia negara yang bisa berdampak negatif terhadap citra bangsa.

8. Dilarang melaksanakan tugas kepemanduan diluar ketentuan lisensi dan bahasa yang telah ditertibkan dalam sertifikat pramuwisata oleh pemerintah yang berwenang

Tujuan utama wisatawan yang mengunjungi kawasan konservasi Batur Kintamani adalah melakukan kegiatan pendakian di gunung Batur.Waktu pendakian yang biasa dilakukan adalah pada pukul 4 di pagi hari.Aktifitas yang dapat dilakukan selain melakukan aktifitas pendakian, wisatawan memperoleh pengalaman melihat matahari terbit di pagi hari (sunrise).Selama pendakian pramuwisata (pemandu) pendakian mendampingi wisatawan dengan memberikan penjelasan atau informasi yang terkait dengan potensi gunung Batur. Namun tidak menutup kemungkinan pemandu pendakian mempromosikan aktifitas lain yang bisa dilakukan di wilayah Batur.

Tabel 2. Frekuensi Hasil Persepsi Wisatawan

\begin{tabular}{lllll}
\hline Variable & Indikator & $\begin{array}{c}\text { Sub } \\
\text { Indicator }\end{array}$ & $\begin{array}{c}\text { Skor } \\
(\%)\end{array}$ & $\begin{array}{c}\text { Kategor } \\
\mathbf{i}\end{array}$ \\
\hline $\begin{array}{l}\text { Outer } \\
\text { directed }\end{array}$ & $\begin{array}{l}\text { Instrumen } \\
\text { tal } \\
\text { leadership }\end{array}$ & $\begin{array}{l}\text { Tanggap } \\
\text { dalam } \\
\text { menghadapi } \\
\text { masalah } \\
\text { (problem } \\
\text { solving) }\end{array}$ & 88.8 & $\begin{array}{l}\text { Sangat } \\
\text { setuju }\end{array}$ \\
& & & \\
& & & \\
\hline & & & \\
\hline & $\begin{array}{l}\text { Fokus pada } \\
\text { kegiatan } \\
\text { pendakian }\end{array}$ & Sangat \\
& & & \\
\hline
\end{tabular}




\begin{tabular}{lll}
\hline Memiliki & 95,6 & Sangat \\
kewaspadaan & & setuju \\
terhadap & & \\
& situasi & \\
pendakian & \\
yang dapat & \\
membahayak & \\
an pendaki &
\end{tabular}

\begin{tabular}{llll}
\hline & $\begin{array}{l}\text { Menjelaskan } \\
\text { aktivitas } \\
\text { masyarakat } \\
\text { lokal di } \\
\text { wilayah } \\
\text { konservasi }\end{array}$ & \multicolumn{1}{c}{$\begin{array}{l}\text { Cukup } \\
\text { setuju }\end{array}$} \\
& & \\
& & \\
& & \\
\hline Menjelaskan 50 & Cukup \\
sumber daya & & setuju \\
alam, & & \\
vegetasi dan & & \\
habitat di & & \\
lokasi & & \\
pendakian & & \\
\hline
\end{tabular}

Sumber: Hasil Penelitian, 2018

\begin{tabular}{lll}
\hline $\begin{array}{l}\text { Menjelaskan } \\
\text { daya tarik }\end{array}$ & 83,2 & $\begin{array}{l}\text { Sangat } \\
\text { setuju } \\
\text { gunung } \\
\text { Batur }\end{array}$
\end{tabular}

\begin{tabular}{|c|c|c|c|c|}
\hline $\begin{array}{l}\text { Inner- } \\
\text { directed }\end{array}$ & $\begin{array}{l}\text { Social } \\
\text { Leadershi } \\
\mathrm{p}\end{array}$ & Humoris & 90,2 & $\begin{array}{l}\text { Sangat } \\
\text { setuju }\end{array}$ \\
\hline & & $\begin{array}{l}\text { Cepat dalam } \\
\text { memberikan } \\
\text { bantuan }\end{array}$ & 87,6 & $\begin{array}{l}\text { Sangat } \\
\text { setuju }\end{array}$ \\
\hline & $\begin{array}{l}\text { communic } \\
\text { ator } \\
\text { mediator }\end{array}$ & $\begin{array}{l}\text { Dapat } \\
\text { menjelaskan } \\
\text { wilayah } \\
\text { pendakian } \\
\text { dengan } \\
\text { menarik dan } \\
\text { bahasa yang } \\
\text { dapat } \\
\text { dimengerti }\end{array}$ & 86 & $\begin{array}{l}\text { Sangat } \\
\text { setuju }\end{array}$ \\
\hline
\end{tabular}

\begin{tabular}{|c|c|c|c|}
\hline & $\begin{array}{l}\text { menjelaskan } \\
\text { potensi } \\
\text { (geologi) } \\
\text { sebagai } \\
\text { potensi } \\
\text { utama } \\
\text { wilayah } \\
\text { konservasi }\end{array}$ & 52,8 & $\begin{array}{l}\text { Cukup } \\
\text { setuju }\end{array}$ \\
\hline $\begin{array}{l}\text { Research } \\
\text { managem } \\
\text { ent role of } \\
\text { motivator }\end{array}$ & $\begin{array}{l}\text { Menjelaskan } \\
\text { peraturan/reg } \\
\text { ulasi di yang } \\
\text { berlaku di } \\
\text { wilayah } \\
\text { pendakian }\end{array}$ & 91,4 & $\begin{array}{l}\text { Sangat } \\
\text { setuju }\end{array}$ \\
\hline $\begin{array}{l}\text { Research } \\
\text { managem } \\
\text { ent role of } \\
\text { environm } \\
\text { ental } \\
\text { interpreter }\end{array}$ & $\begin{array}{l}\text { Concern } \\
\text { pada potensi } \\
\text { budaya } \\
\text { dengan } \\
\text { memberikan } \\
\text { penjelasan } \\
\text { terhadap } \\
\text { budaya lokal }\end{array}$ & 60,6 & Setuju \\
\hline
\end{tabular}

Berdasarkan hasil interpretasi persepsi wisatawan pada tabel 2 dijelaskan peran pramuwisata lokal di kawasan konservasi Geopark Batur Kintamani terdapat tiga sub indikator berada pada kategori cukup setuju dengan skor 52,8 persen, 59,4 persendan 50 persen. Sub indicator dengan kategori tersebut merupakan sub indicator penting yang menjelaskan idealnya peran utama pramuwisata di wilayah konservasi. Namun sub indikator tersebut ternyata memperoleh hasil yang rendah.

Luaran dalam penelitian ini dalam bentuk model pengembangan capacity building pramuwisata dalam perannya menafsirkan dan mempromosikan potensi Geopark sebagai wilayah konservasi. Fokusnya adalah merekomendasikan pada program pengembangan kemampuan pramuwisata melalui pelatihan pentingnya pemahaman tentang wilayah konservasi, dapat mengkomunikasikan dan menginterpretasikan potensiwilayah, mempromosikan dampak minimal dari aktivitas wisata, memastikan keberlanjutan lingkungan alam dan budaya, dan memotivasi wisatawan yang berkunjung untuk mengevaluasi kualitas hidup dalam kaitannya dengan masalah konservasi/perlindungan ekologis atau budaya yang lebih besar.Bagi wisatawan model pengembangan Capacity Building pramuwisata ini diharapkan dapat meningkatkan nilai edukasi dan rekreasi dari kegiatan pariwisata geopark. 


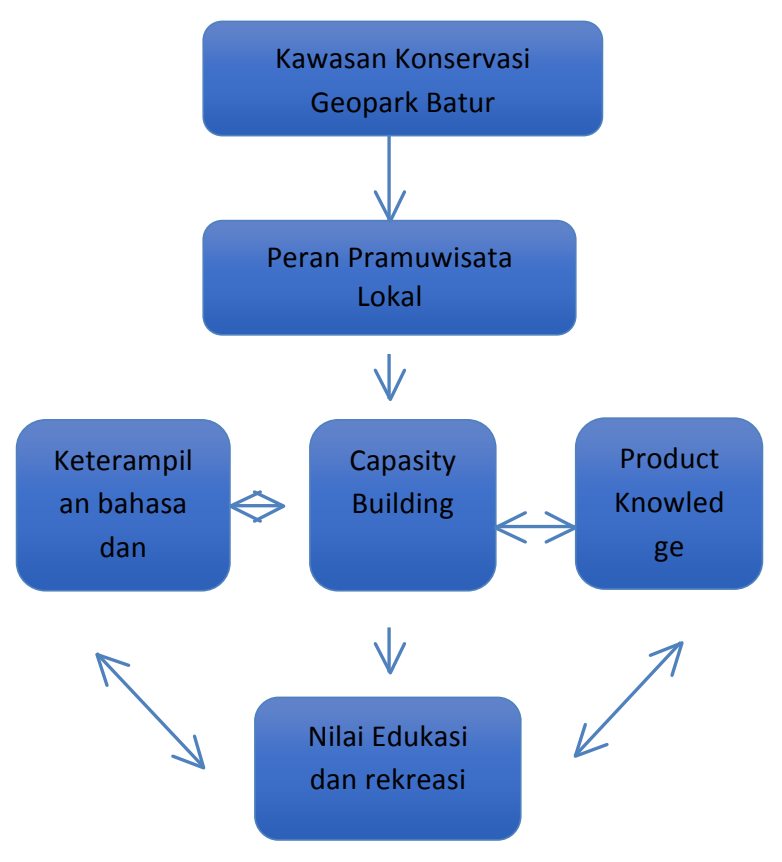

Gambar 2. Model

Pengembangan Capacity

Building Pramuwisata di Wilayah

Konservasi Geopark Batur

\section{SIMPULAN DAN SARAN \\ Simpulan}

Penelitian ini mengidentifikasi persepsi wisatawan terhadap peran pramuwisata di wilayah konservasi Geopark Batur Kintamani.Keberadaan pramuwisata lokal sebagai pemandu wisatawan dalam aktivitas pendakian di gunung Batur menentukan keberlanjutan suatu kawasan konservasi.Dari variable yang telah ditentukan, ditemukan bahwa variable utama dari peran pramuwisata yaitu tiga sub indikator berada pada kategori cukup setuju dengan skor 52,8 persen, 59,4 persen dan 50 persen. Sub indicator dengan kategori tersebut merupakan sub indicator penting yang menjelaskan idealnya peran utama pramuwisata di wilayah konservasi. Namun sub indikator tersebut ternyata memperoleh hasil yang rendah.

\section{Saran}

Berdasarkan hasill simpulan tersebut maka Sangat dibutuhkan skill dalam menginterpretasikan komunikasi informasi kepada wisatawan terhadap prinsip lingkungan dan konservasi. Melalui pelatihan kepemanduan dapat menentukan keberhasilan dalam penyampaian pengetahuan tentang wilayah konservasi dan keterampilan juga dibutuhkan untuk dapat meningkatkan kapasitas pemandu dalam melibatkan wisatawan secara efektif, mempengaruhi perilaku wisatawan dalam melihat lingkungannya dan memperkaya pengalaman wisatawan. 


\section{Kepustakaan}

Armstrong, E., \& Weiler, B. (2002). Getting the message across: An analysis of messages delivered by tour operators in protected areas. Journal of Ecotourism, 1(2\&3), 104-121.

Cohen, E. (1985). The tourist guide: The origins, structure and dynamics of a role. Annals of Tourism Research, 12(1), 5-29.

Min, J. C. H. (2011). A short-form measure for Assessment of emotional intelligence for tour guides: development andevaluation tourism management. Tourism Management, 33(1), 155-167.

Newsome, D., Dowling, R., \& Leung, Y-F. (2012). The nature and management of geotourism: A case study of twoestablished iconic geotourism destinations. Tourism Management Perspectives, 2-3, 19-27.

Ormsby, A., \& Mannle, K. (2006). Ecotourism benefits and the role of local guides at Masoala National Park,Madagascar. Journal of Sustainable Tourism, 14(3), 271-287.

Paskova, M. (2012). Tourism environmentalism. Czech Journal of Tourism, 1(2), 77-113.

Pereira, E. M., \& Mykletun, R. J. (2012). Guides as contributors to sustainable tourism? A case study from theAmazon. Scandinavian Journal of Hospitality and Tourism, 12(1), 74-94.

Pond, K. L. (1993). Interpretation and the role of the guide. The professional guide. dynamics of tour guiding. VanNostrand Reinhold: New York.

Randall, Carleight. (2008). Visitor Perceptions of the role of tour guides in natural areas. Journal of Sustainable Tourism. Vol.17, No. 3, May 2009, 357-374.
Weiler, B., \& Walker, K. (2014). Enhancing the visitor experience: Reconceptualising the tour guide"s communicativerole. Journal of Hospitality and Tourism Management, 21, 90-9. 